\title{
36. SEDIMENTARY HIATUSES IN THE VENEZUELAN BASIN
}

\author{
Terence Edgar, Scripps Institution of Oceanography, La Jolla, California \\ Troy Holcombe, U. S. Naval Oceanographic Office, Chesapeake Beach, Maryland \\ John Ewing, Lamont-Doherty Geological Observatory, Palisades, New York \\ and \\ William Johnson, U. S. Naval Oceanographic Office, Washington, D. C.
}

\section{INTRODUCTION}

One of the most salient features of the sedimentary strata underlying the Venezuelan Basin is that they are remarkably uniform in thickness and acoustic character over most of the basin. The sequence down to Horizon $\mathrm{B}^{\prime \prime 1}$ varies little from the 600 to 800 meter range of thickness ${ }^{2}$. Where variations are observed, they occur in the same sense above and below Horizon $\mathrm{A}^{\prime \prime}$, indicating that uniform depositional conditions existed over long periods of time (Edgar et al., 1971) and demonstrating tectonic stability of the Caribbean crust (Ewing et al., 1967). In the southern part of the Venezuelan Basin, however, the sediments are anomalously thin; Horizons $\mathrm{A}^{\prime \prime}$ and $\mathrm{B}^{\prime \prime}$ converge to the extent of being indistinguishable; and the sequence above Horizon $\mathrm{A}^{\prime \prime}$ is reduced to below $0.2 \mathrm{sec}$ reflection time, or less than a third the average thickness.

The work being reported here has been to delineate the extent of this sediment thinning; to determine the relationship of the thinning patterns to the underlying structure; and to identify, if possible, the sedimentary or tectonic processes which have produced the thinning. To do this we have constructed isopach maps of the sediment thickness above and below Horizon $\mathrm{A}^{\prime \prime}$, and a structure contour map of Horizon B", using extensive $(18,000 \mathrm{~km})$ seismic profiler coverage provided by the Lamont-Doherty Geological Observatory, the U.S. Naval Oceanographic Office, the Deep Sea Drilling Project, the U. S. Geological Survey, and Texas A\&M University. These were supplemented by stratigraphic data from three holes drilled by the Glomar Challenger: Site 146/149 was drilled through a "typical" sediment thickness; Site 150 is located where the sediments are thinnest; and Site 29 (Leg 4) is located halfway between the other two where the strata are of intermediate thickness.

\footnotetext{
${ }^{1}$ See introductory chapter of this volume for definition and discussion of Horizons $\mathrm{A}^{\prime \prime}$ and $\mathrm{B}^{\prime \prime}$.

${ }^{2}$ These thicknesses are based upon average sound velocities in the sediments of $1.62 \mathrm{~km} / \mathrm{sec}$ in the upper strata (down to Horizon $\mathrm{A}^{\prime \prime}$ ) and $2.47 \mathrm{~km} / \mathrm{sec}$ in the lower beds (between Horizons $A^{\prime \prime}$ and $B^{\prime \prime}$ ). These velocities were determined from comparison of drilled depths and seismic reflection times at Site $146 / 149$, and they were confirmed by velocimeter measurements made on the samples on shipboard, by some measurements made on samples under pressure (Fox and Schrieber, this volume), and by sonobuoy measurements (Ludwig, L-DGO, personal communication). These velocities are considered to be reasonable for the Venezuelan Basin as a whole, in view of the aforementioned uniformity of the sequence over broad areas.
}

\section{SEISMIC PROFILER RESULTS}

The study area in the Venezuelan Basin is shown in Figure 1, and the track coverage for the isopach and structure contour maps is shown in Figure 2. The seismic profiler record in Figure 3 was made by Glomar Challenger en route from Site 146/149 to the continental margin of South America (Curacao Ridge) along section line D-D' (Figure 4) and it clearly shows the area of thin sediment where Site 150 was drilled. The track passed within $3 \mathrm{~km}$ of Site 29 drilled on Leg 4 . The area of thin sediment appears to be associated with a structural rise, and the axis of thinning overlies acoustic basement which dips southward away from the structural axis. Horizons $\mathrm{A}^{\prime \prime}$ and $\mathrm{B}^{\prime \prime}$ are not clearly identifiable south of the drilling sites, but they may be traced with greater certainty elsewhere along the southern margin of the Venezuelan Basin.

A structure contour chart to the top of the seismic reflection Horizon $\mathrm{B}^{\prime \prime}$ outlines the structural elements of this part of the Venezuelan Basin (Figure 4). Structural relief is low over most of this area (generally less than 300 meters), consisting of broad and gentle structural ridges and valleys. There are two basic structural trends shown, a northeast-southwest trend dominating the eastern part of the area and a northwest-southeast trend in the western part. The overall structural pattern parallels the major trends of thin sediment (northwestern trend in the west and a northeastern trend in the east) as noted above. A trough in the vicinity of $14^{\circ} \mathrm{N}, 69^{\circ} \mathrm{W}$ appears as a dominant feature of the northeast trending structures, and it can be traced to the Curacao Ridge. The broad, gentle aspect of the structure is broken abruptly by basement cones and ridges in the northern part of the area. These features, subsequently buried by sediments, are probably of volcanic origin.

An isopach map of the Horizon $A^{\prime \prime}$ to $B^{\prime \prime}$ interval (Figure 5) outlines the area of extreme sediment thinning, where $\mathrm{A}^{\prime \prime}$ and $\mathrm{B}^{\prime \prime}$ are indistinguishable on the profiler records (hachured area). The width of the thinning is 30 to $60 \mathrm{~km}$; its trend is dominantly northwest-southeast. It is barely discernible west of about $70^{\circ} \mathrm{W}$. There is also a suggestion of a thinning trend in a northeasterly direction between $67^{\circ} \mathrm{W}$ and $68^{\circ} \mathrm{W}$ so that the resulting pattern looks rather like a "Y". Figure 5 also shows the location of those reflection profiler records which are digitized and plotted in terms of true thickness in Figure 6. These plots have been greatly foreshortened, and reference to Figure 3 is advised for comparison between D-D' and the original seismic 


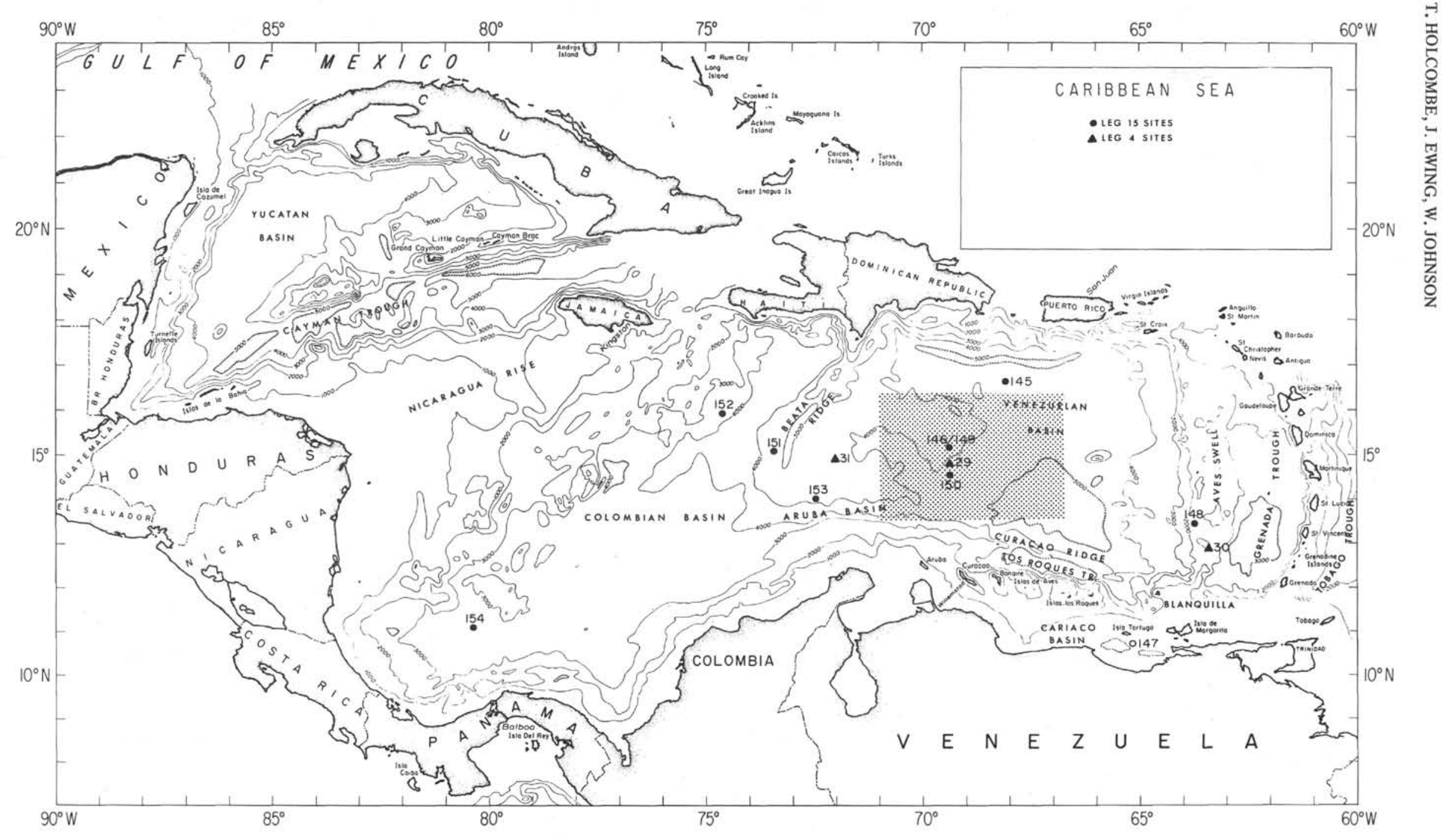

Figure 1. Bathymetric chart of the Caribbean Sea with the shaded rectangle being the area of study. 


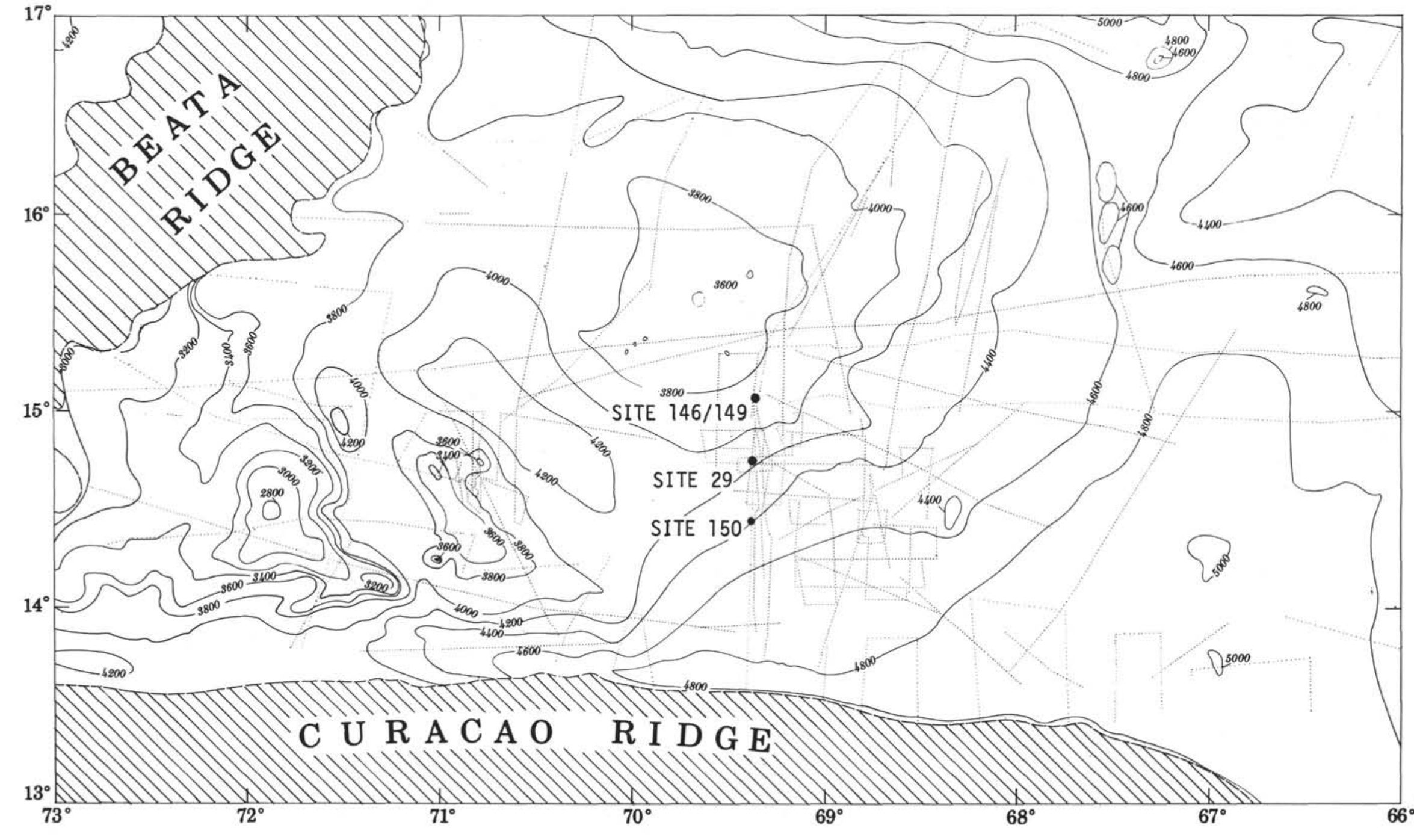

Figure 2. Bathymetry of the study area showing track control for isopach and structure contour maps. 


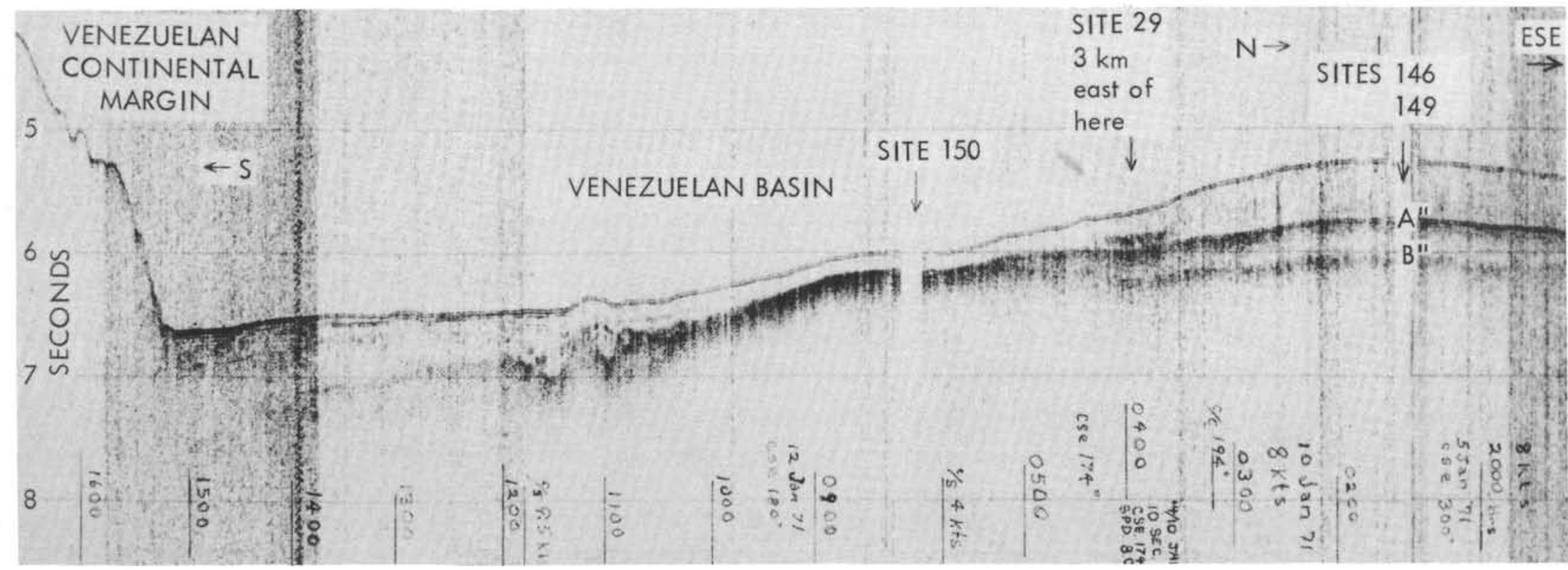

Figure 3. Profiler record and track made by Glomar Challenger en route from Site 146/149 to Site 150. Track passed within a few kilometers of Site 29. Record extends to base of the Curacao ridge. 


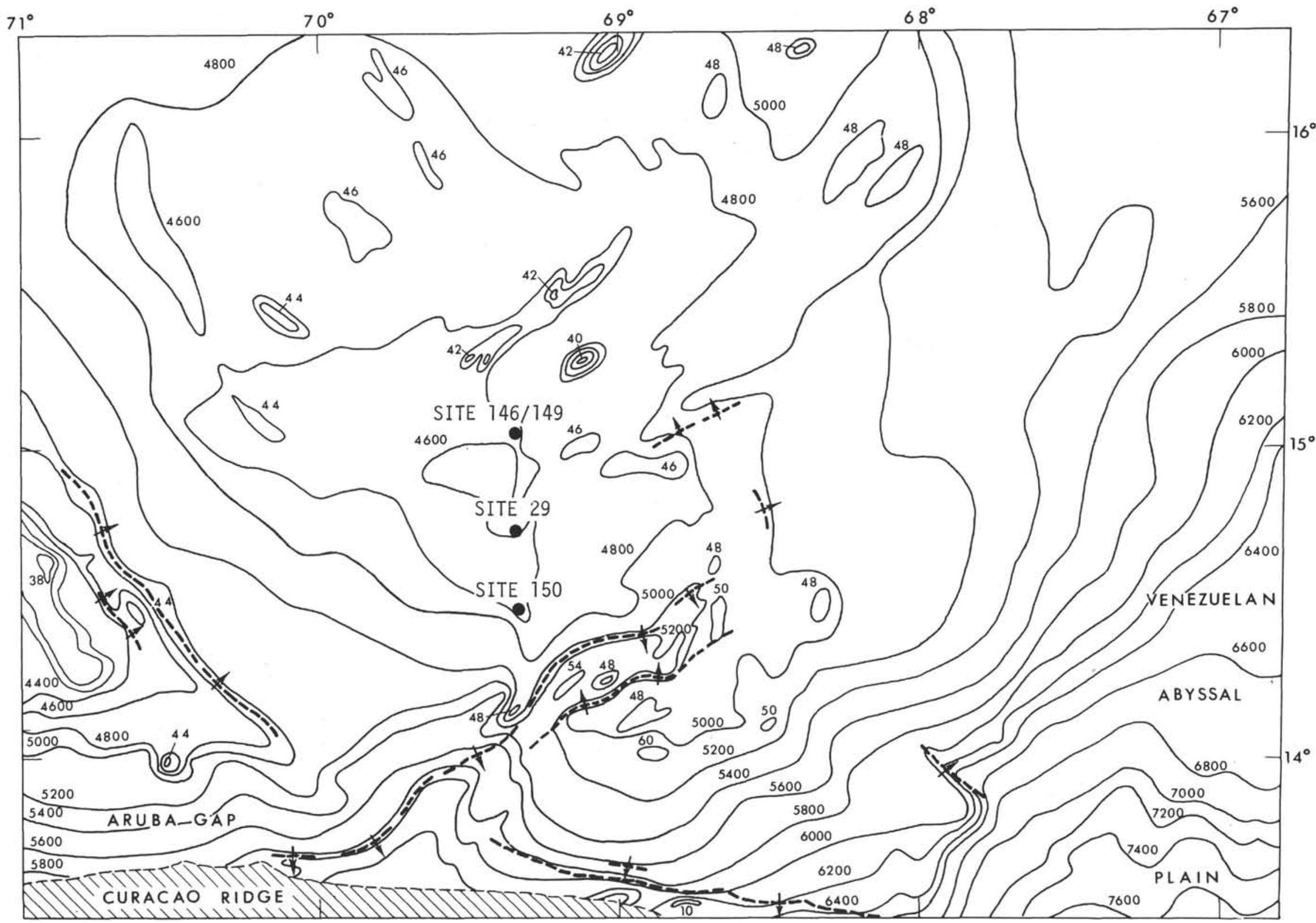

Figure 4. Structure contour chart on reflecting Horizon B" from sea level. Contour interval 200 meters. Water depth is corrected by Matthews Tables. Sediment thickness calculated using $1.62 \mathrm{~km} / \mathrm{sec}$ for sediments above Horizon $A^{\prime \prime}$ and $2.47 \mathrm{~km} / \mathrm{sec}$ for sediments between $A^{\prime \prime}$ and $B^{\prime \prime}$. Arrows point to the downthrow side of normal faults or monoclines. 


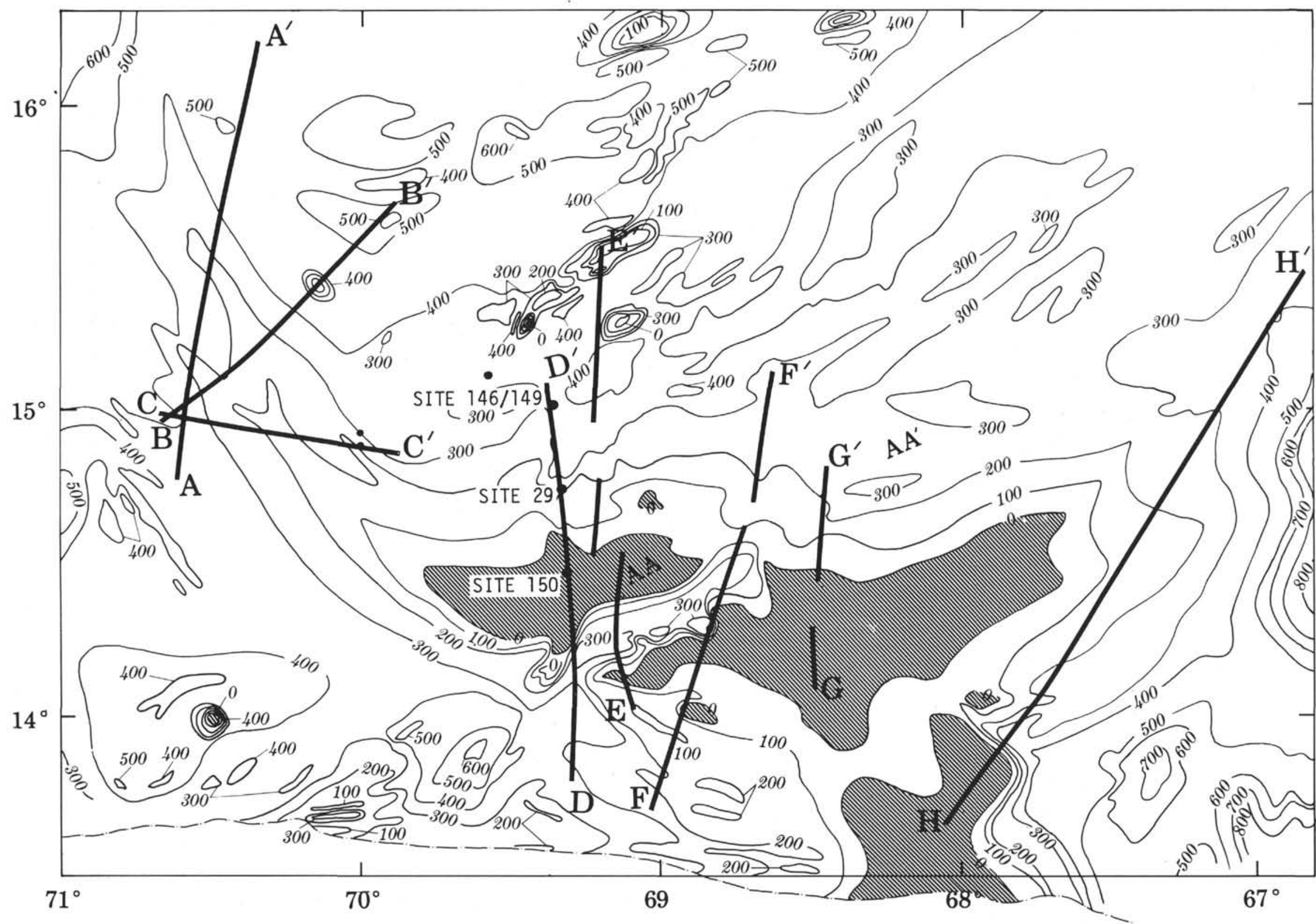

Figure 5. Isopach map of the Horizon $A^{\prime \prime}$ to $B^{\prime \prime}$ interval in the southern Venezuelan Basin. Thickness measurements are from the top of the first prominent reflector in the $A^{\prime \prime}$ horizon to the top of the first prominent reflector in the $B^{\prime \prime}$ horizon. Computation of thickness is based on an average sound velocity of $1.47 \mathrm{~km} / \mathrm{sec}$ determined from a caomparison of reflection time and drill depths in Site 146/149. The section lines A-A' through $H-H^{\prime}$ define the locations of profiles shown in 


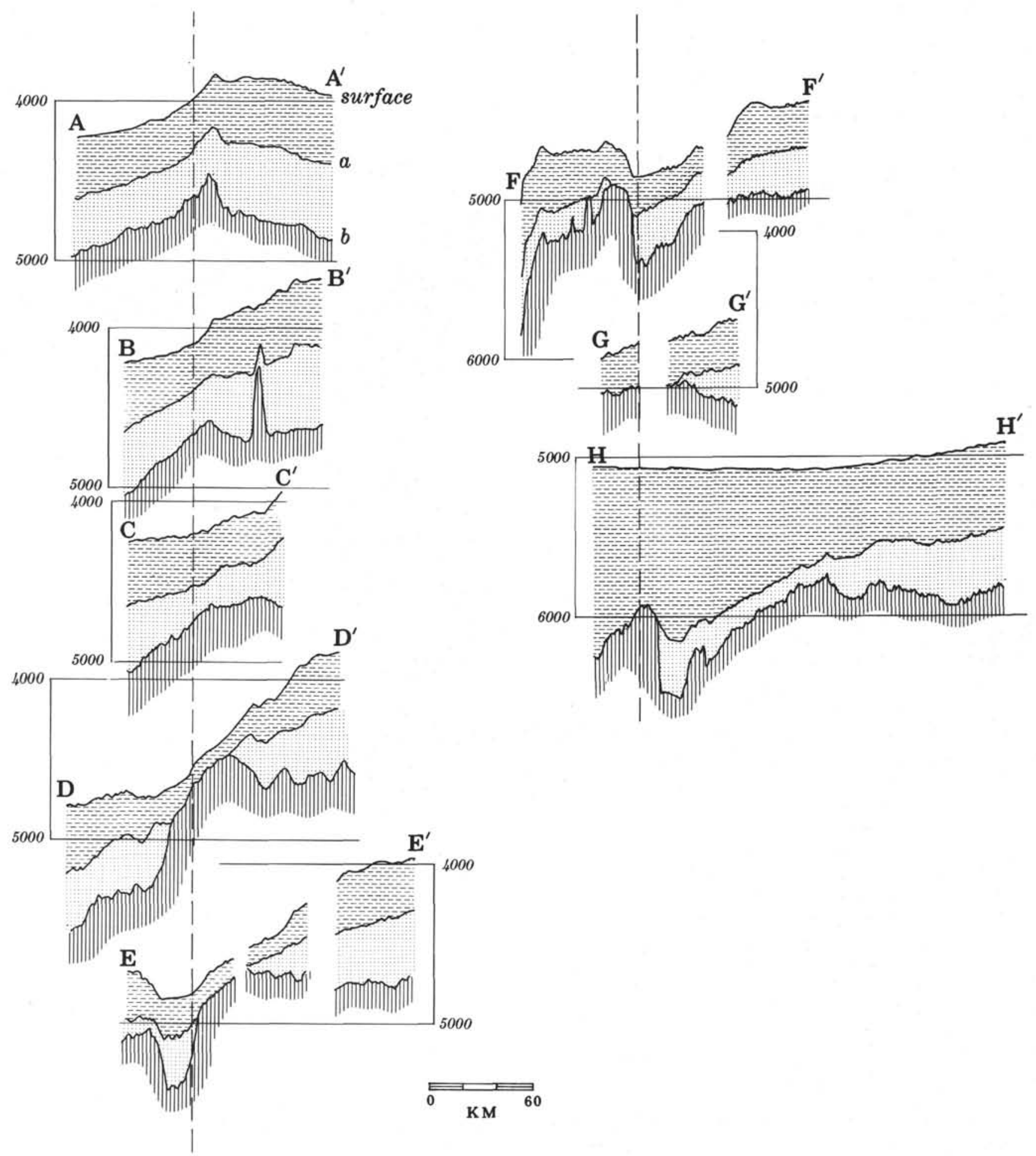

Figure 6. Structure sections along section lines $A-A^{\prime}$ through $H-H^{\prime}$. The vertical dashed line represents the approximate axis of the thin sediment belt as defined by the isopachs in Figure 5. Note that the axis of thinning coincides with a southward dip of Horizon $B^{\prime \prime}$, the acoustic basement. Depth to the ocean-sediment interface is in corrected meters using Matthews tables. Subsurface depths have been computed by assuming average sound velocities of $1.62 \mathrm{~km} / \mathrm{sec}$ in the surface to $A^{\prime}$ interval, and $2.47 \mathrm{~km} / \mathrm{sec}$ in the $A^{\prime \prime}$ to $B^{\prime \prime}$ interval. 
record. In each case the sediments thin where there is a structural rise and in most cases maximum thinning is on the south side. Profile F-F' shows an example of thinning on the north side. Profiles E-E' and F-F' show the northeast trending structural trough seen in Figure 4, which is characterized by thicker sediments than the surrounding area. South of the area of thinning, the sediment below Horizon $\mathrm{A}^{\prime \prime}$ reaches maximum thickness in the southwest extension of this structural trough and in the structural basin underlying the Venezuelan Abyssal Plain. Locally the thickening may be in part a result of terrigenous input from South America. North of the area of thinning, sediment below Horizon $\mathrm{A}^{\prime \prime}$ is fairly uniform in thickness varying between 300 and 400 meters with local increases to 500 meters and above. In contrast to the area south of the belt of thinning, there is no obvious relationship here between thickness and structural elevation and several of the local thickness maxima occur in structurally high areas (compare Figures 4 and 5).

An isopach map of the interval above Horizon $\mathrm{A}^{\prime \prime}$ is shown in Figure 7. The sediments in this interval thin in the same general pattern, though not as extremely, as those underlying $\mathrm{A}^{\prime \prime}$, underscoring the observation referred to in the introduction to this paper that the environment of sedimentation in most of the Venezuelan Basin has varied little between the time of formation of Horizon $\mathrm{B}^{\prime \prime}$ and the late Tertiary. A linear axis of thickening occurs in this interval north of, but parallel to, the axis of thinning (see also F-F', Figure 6). Beneath the Venezuelan Abyssal Plain and the Aruba Gap, thick accumulation of turbidites preclude determination of thickness of the pelagic fraction of post- $\mathrm{A}^{\prime \prime}$ sediments from seismic reflection records. Total thickness of the post-B" sediment column increases southward toward the base of the Curacao Ridge, reaching 1400 to 1800 meters beneath the Aruba Gap and 3,000 to 4,000 meters beneath the Venezuela Abyssal Plain (Case et al., 1972).

\section{DRILLING RESULTS}

The drilling results pertinent to this problem are best displayed in the diagram on Figure 8 (see Figure 3 for the profiler record showing the setting at each site). Thick sediments in the area of Site 146/149 represent an essentially complete section. At Site 150, where the sediments are thinnest, there are two major hiatuses, Santonian to Paleocene/Early Eocene (27 m.y.) and Early Eocene to Early Miocene (26 m.y.). In the entire interval from Santonian to Early Miocene (53 m.y.) only Paleocene/Early Eocene sediments can be identified.

The Santonian-Eocene unconformity is not clearly defined because of poor core recovery and poor preservation of the fossils, but there is certainly a significant sedimentary section missing (Figure 9) between Cores $2 \mathrm{~A}$ (119 to 128 meters Paleocene/Early Eocene) and 9 (150 to 159 meters, Coniacian/Santonian). Cores 6 through 8 (123 to 150 meters) contain poorly preserved radiolarians of Cretaceous age and some moderately well-preserved radiolarians (Core 7) of Early Eocene age (Buryella clinata Zone). It cannot be said with certainty whether the Cretaceous forms are reworked or the Eocene radiolarians slumped in from higher in the hole.
Consequently, it is not clear whether the hiatus is between Cores $2 \mathrm{~A}$ and 6 or between Cores 7 and 9 .

The younger unconformity can be more clearly identified. Well-dated Early Miocene (Globigerinoides primordius) sediments of Core 5 (105 to 114 meters) lie just a few meters above the Early Eocene (Globorotalia edgari) sediments of Core 2A (119 to 128 meters). The Miocene core contains a number of large. iron-rich $\mathrm{Fe}-\mathrm{Mn}$ nodules, some 3 or $4 \mathrm{~cm}$ across, and also numerous micronodules. Nodules were also found in the Early Miocene sediments of Core 4.

The upper conformity may be present in the sediments of Site 29, where the Oligocene section is absent in the recovered section. However, the missing sediments may be present in a condensed section of the uncored interval overlying the Eocene section.

The depth of the oldest Cretaceous sediments lying on the dolerite is almost identical at Sites 146/149 and 150, but the limestones at Site 146/149 are hardly comparable with the calcareous clays, chalks, and marls at Site 150. Volcanic ashes and cherts are common to both areas.

\section{DISCUSSION}

From the seismic reflection data (Figures 3-7), it has been established that the axis of sediment thinning is curvilinear in shape; that it overlies rather broad, low relief structural highs; and that it lies south of the structural axis on southward-dipping basement. From the drilling results it is apparent (Figure 8) that at least two factors are responsible for the thin sediment at Site 150; that which produced the hiatuses and the overall decrease in biogenic calcium in the sediment.

The sediments at Site 150 are poorer in biogenic calcium carbonate than those at Site $146 / 149$, but this is a minor factor in overall thinning of the sediments in the area around Site 150 . In fact, the deepest recovered Pliocene core (clay and calcareous clay) at Site 150 is at 55 meters, whereas the Miocene-Pliocene boundary at Site 29 is at 33 meters (calcareous clay) despite the fact that Site 29 is in shallower water (by 300 meters) and was drilled in a thicker section (seismic record, Figure 3). This is particularly significant because the seismic record shows that the post- $A^{\prime \prime}$ sediments thin from Site 29 to Site 150. The thinning at Site 150 takes place in the Eocene, Oligocene, and Miocene sediments, but in post-Miocene time the sedimentation accumulation rate increased significantly, suggesting a change in the bottom regime at that time.

The major question to be answered is, what sedimentary or tectonic agencies have produced the observed hiatuses? Several possibilities may be discounted. It is unlikely that short periods of erosion, in which the sediment cover was stripped away, followed long periods of uniform deposition. The evidence for tectonic stability, and the absence of evidence of beveling of older strata, would seem to discount any short-lived, catastrophic changes in the sedimentation regime. Accounting for the changes in thickness due to gravity movement of material downslope would seem reasonable in view of the coincidence of the thinning axis with a southward-sloping basement, but this factor may be discounted as being of other than minor significance. The basement slope is very gentle in this region. In typical hilly 


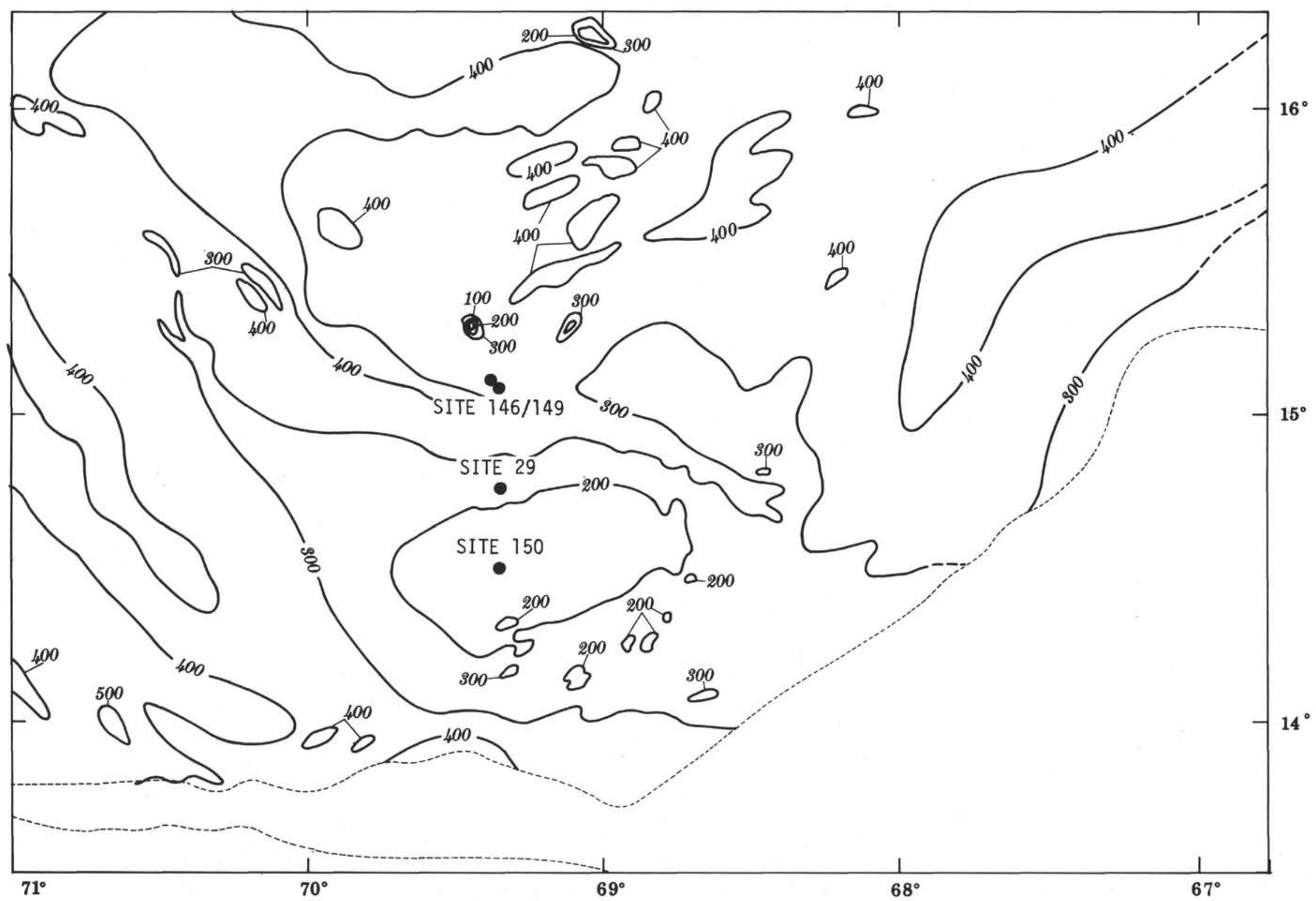

Figure 7. Isopach map of the surface to $A^{\prime \prime}$ interval in the southern Venezuelan Basin. Thickness measurements are from the ocean-sediment interface to the top of the first prominent reflector in the $A^{\prime \prime}$ horizon. Computation of thickness is based on an average sound velocity of $1.62 \mathrm{~km} / \mathrm{sec}$ determined from a comparison of reflection time and drill depths in Site 146/149. The locations of Sites 146/149, 29 and 150 are shown. 

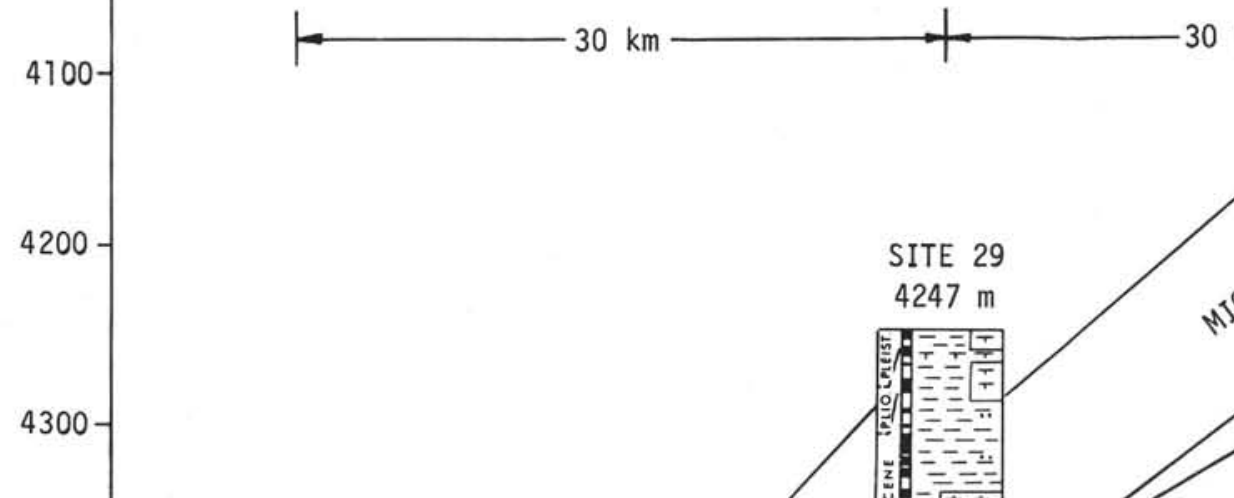

4600-

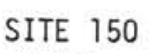

4400
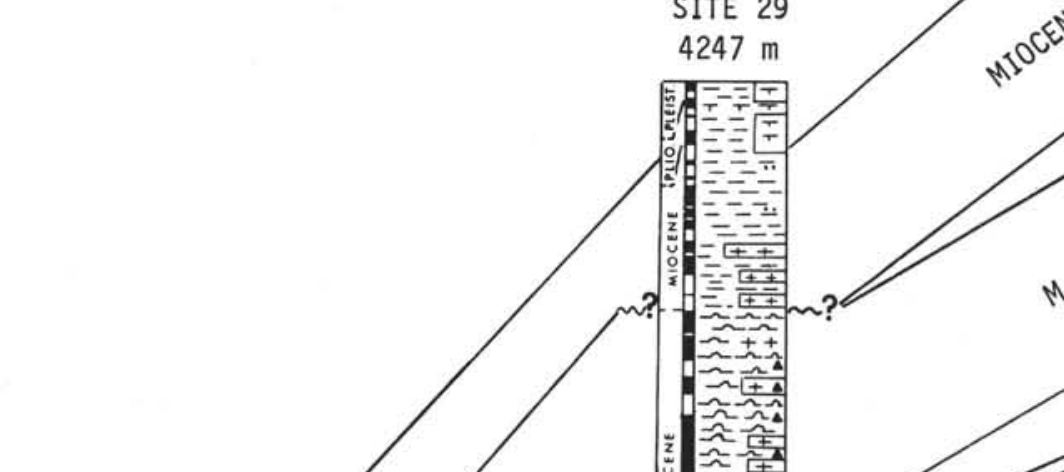

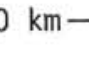

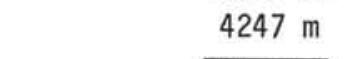

>

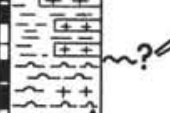

?
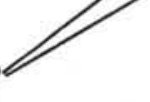

.
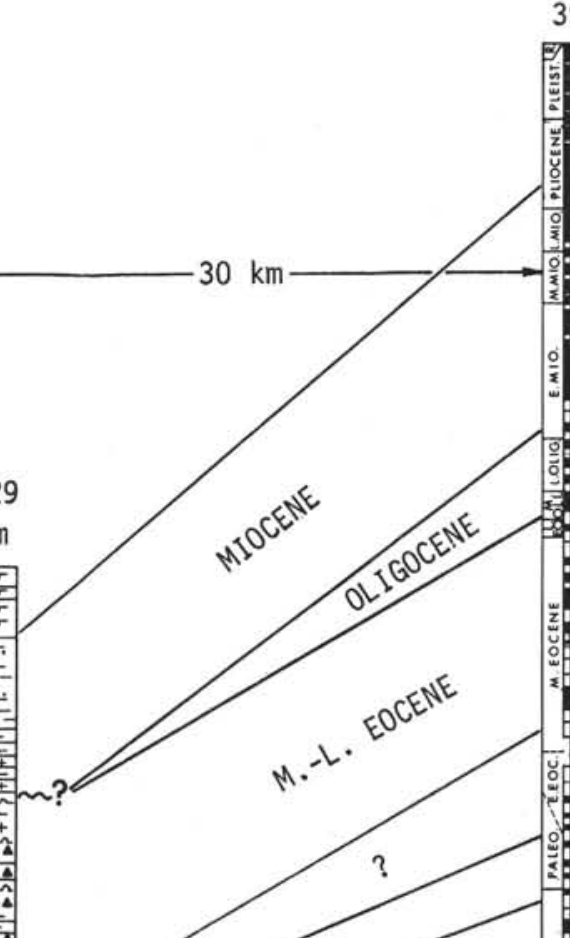


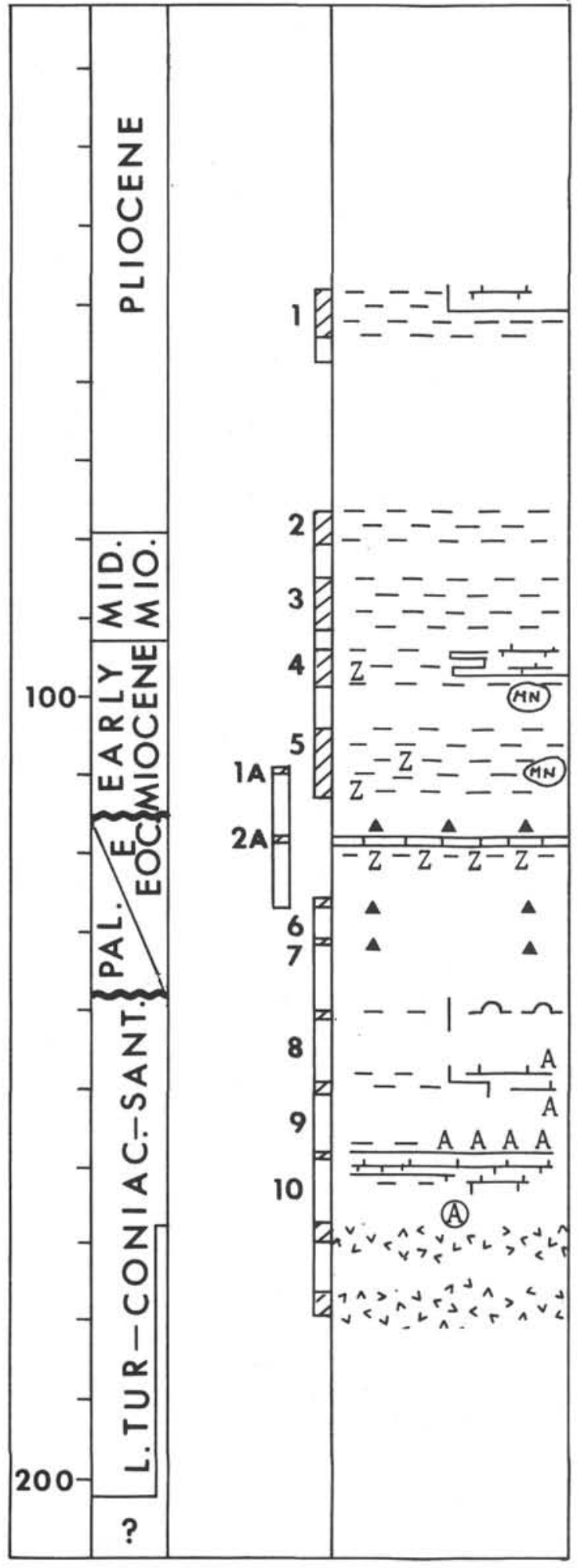

Figure 9. Section of Site 150 showing coring sequence. Core $1 A$ is a soupy drilling mix and worthless for dating. Core 6 contained only indurated chert.

currents. Offset of the axis of sediment thinning to the south of the structural axis is indicative of flow in a westerly direction. The axis of thickening north of the structural axis is probably a sediment-drift feature, suggestive of a bottom-current regime favoring net deposition north of the structural axis. Iron-manganese nodules, commonly associated with vigorous bottom currents and inhibited sedimentation or erosion, were found in early Miocene sediments that directly overlie the interval of hiatuses.

Major hiatuses reported on a number of Deep Sea Drilling Legs $(1,2,3,4,11,12,13,14$, and 17) have been summarized by Pimm and Hayes (1972). They concluded that hiatuses in the North Atlantic resulted from erosion by bottom currents, and in the South Atlantic they are due to dissolution and nondeposition on the Mid-Atlantic Ridge and erosion on the Rio Grande Rise. The dissolution was proposed primarily on the basis that only sites on the lower portions of the ridge, close to the depth of carbonate compensation, show hiatuses. Figure 10 is their summary of hiatuses in the Atlantic, but with the addition of Site 150 and the approximate age of the sediment where the hole was terminated. Based on sediment data, Pimm and Hayes conclude that the eastern North Atlantic currents were less vigorous than those of the western North Atlantic and that they may have caused hiatuses by limited sedimentation rather than by active erosion (Pimm, personal communication). Extensive hiatuses in the western Atlantic were caused by active erosion, removing the late Cretaceous sediments. Consequently, they concluded that the currents became active in the Eocene (Figure 10, eastern North Atlantic). The Eocene-Oligocene hiatus at Site 150 supports this conclusion and fits into the concept of an oceanwide event, but the presence of Paleocene/early Eocene sediment overlying Turonian-Coniacian sediments indicates that significant currents were present earlier than the Eocene. The presence of early Eocene limestone and chert (Core $2 \mathrm{~A})$ is probably the result of local tectonic events temporarily reducing the current regime rather than representing an oceanwide event, since sediments of this age are not found separating unconformities in other areas.

The presence of a bottom-current regime in the Venezuelan Basin in the late Cretaceous and early Tertiary, and its apparent termination in the Miocene, poses interesting questions on the tectonic history of the circum-Caribbean region, particularly regarding the opening, closing, and depth of sills, and the time of closing of marine connections between the Atlantic and Pacific through the Caribbean.

\section{CONCLUSION}

Thinning of the pelagic sediments in the southern Venezuelan Basin, evidenced primarily by hiatuses prior to and following the early Eocene, is attributed to current activity that was particularly effective in eroding and preventing sedimentation along a positive basement structure. Some thinning may also be attributed to the loss of biogenic carbonate due to dissolution in the deeper water in the southern part of the basin. Of these two processes, the current activity has been dominant in reducing the overall sediment thickness, resulting in a total loss of 53 million years of sedimentary history. 


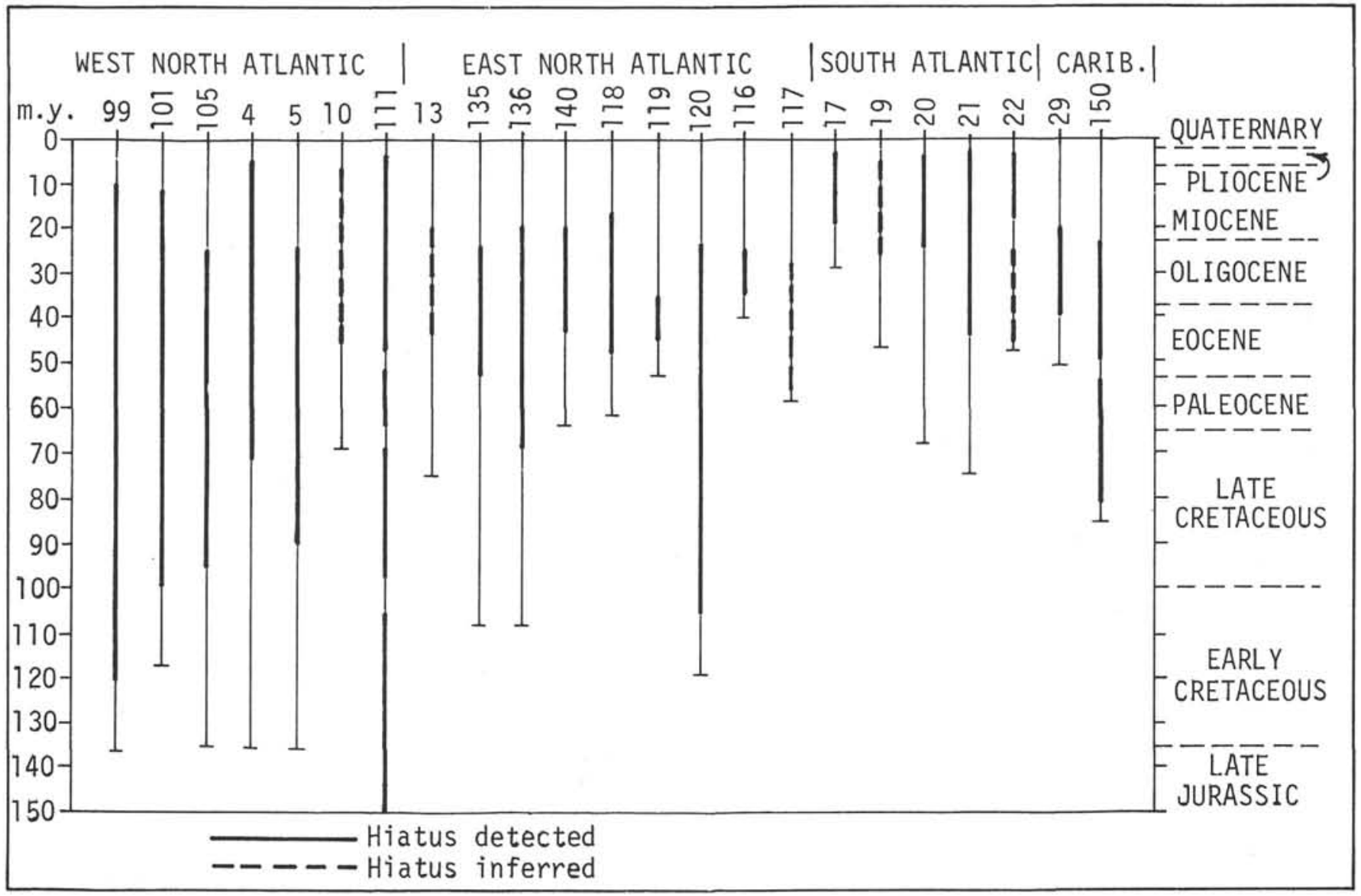

Figure 10. Time span of hiatuses in the Atlantic Ocean and Caribbean Sea (modified from Pimm and Hayes, 1972).

\section{ACKNOWLEDGMENTS}

The authors would like to thank J. Mathews, W. Geddes, J. Allen, and others of the Deep Ocean Surveys Division, U.S. Naval Oceanographic Office, and the scientific complements and crews of the USNS Kane and the USNS Wilkes, for their contributions in the collection of data. L. Hemler and S. Dorey of the Ocean Floor Analysis Division, U. S. Naval Oceanographic Office, processed on a computer all the data used in this report. Also thanks are due to $M$. Ewing, M. Talwani, J. Worzel, J. Hiertzler, C. Windisch, R. Leyden, M. Langseth, R. Wall, M. Truchan, W. Ryan, and S. Eittreim for data compiled from cruises in the Caribbean Sea directed by them. Lamont-Doherty data were collected with support from Contract N00014-67-A-0108-004 with the Office of Naval Research and grants NSF GA-27281 and NSF GA-28338 from the National Science Foundation. The efforts of the officers and crews aboard the Lamont vessels Vema and Robert D. Conrad are greatly appreciated. On the Glomar Challenger, Robert Iuluicci and Peter Garrow were instrumental in maintaining the profiling equipment. J. Case of the U. S. Geological Survey, W. Bryant and L. Roemer of Texas A\&M University kindly made their seismic reflection data available.

\section{REFERENCES}

Case, J. E. et al., 1972. Regional gravity anomalies, Venezuela continental borderland: U. S. Geological Survey open file report.

Edgar, T., Ewing, J., and Hennion J., 1971. Seismic refraction and reflection in the Caribbean Sea: Am. Assoc. Petrol. Geol., J. 55, p. 833.

Ewing, J., Talwani, M., Ewing, M., and Edgar, T., 1967. Sediments of the Caribbean: Internat. Conf. Tropical Oceanog. Proc., U. of Miami, p. 88.

Pimm, A. C. and Hayes, D. E., 1972. General Synthesis: Initial Reports of the Deep Sea Drilling Project, Volume XIV, Washington (U.S. Government Printing Office), p 955. 